\title{
Quantifying aphid predation rates of generalist predators in the field
}

\author{
JAMES D. HARWOOD and JOHN J. OBRYCKI \\ Department of Entomology, University of Kentucky, S-225 Agricultural Science Center North, Lexington, KY 40546-0091, USA; \\ e-mail: James.Harwood@uky.edu
}

Key words. Gut-content analysis, polyclonal antisera, monoclonal antibodies, PCR, biological control, generalist predators

\begin{abstract}
The community of predators within agroecosystems has the potential to restrict aphid populations, especially early in the season before exponential increases in density and prior to the arrival of specialist natural enemies. Although direct observations of predation, laboratory feeding trials and manipulative field studies have been used to estimate levels of biological control exerted by different species (or potentially negative interactions between them), it is often difficult to extrapolate results to naturally occurring interactions in the field.

Over 100 investigations have utilized gut-content analysis to estimate aphid predation rates by predators. Throughout the last century, gut dissection, which enables the visual identification of aphid body parts, has been used in over $50 \%$ of studies although accurate identification and quantification of predation is difficult. Other techniques have included radio-labelling of prey, dissection of faecal samples, electrophoresis, stable isotope analysis and use of polyclonal antisera. In recent studies of invertebrate predation, monoclonal antibodies have been the most frequently applied technique but advances in molecular biology have enabled the detection of species-specific DNA sequences. The use of these applications to quantify predation by aphidophagous predators will be reviewed, with emphasis on potential sources of error and difficulties of quantitative interpretation. Despite the considerable focus currently directed towards molecular approaches, antibody-based techniques are likely to remain an important tool for studying predation rates of pests in the field, especially when antibodies have already been developed. However, the study of multiple predation events within complex generalist predator food webs is only likely through the detection of species-specific DNA sequences using molecular techniques.
\end{abstract}

\section{INTRODUCTION}

The role of generalist natural enemies in biological control and their interactions with prey, of which aphids constitute one part, has received considerable attention (Symondson et al., 2002) due to their importance in agroecosystems and the unsustainable nature of conventional methods of pest control. Pests of agroecosystems are readily accessible at various strata and are attacked by a range of natural enemies (pathogens, parasitoids and predators) which interact in complex ways (Sunderland et al., 1997) but the most valuable attribute of the generalist predator community is that most species subsist on alternative, non-pest prey. They are therefore present within the crop prior to colonization by pests, either performing a "lying-in-wait" strategy (Murdoch et al., 1985; Chang \& Kareiva, 1999) or building up their populations and impacting pests with favourable predator : pest ratios (Settle et al., 1996). Although generalist predators are unlikely to impact pests once their populations increase exponentially, it has been suggested that they could have a greater role than individual specialists acting alone (Murdoch et al., 1985).

A fundamental premise to using predators in biological control is their ability to consume large numbers of pests. Many generalist aphidophagous predators do not exhibit this behaviour. Not only do they feed on a diverse range of prey which are often of higher nutritional quality than aphids (Bilde et al., 2000; Bilde \& Toft, 2001) but many are competitive and/or cannibalistic (Evans, 2004; Hoogendoorn \& Heimpel, 2004). This concept whereby overall regulation of herbivore populations could be reduced due to interactions between natural enemies was demonstrated in Chrysoperla carnea (Stephens) (Neuroptera: Chrysopidae). This predator was ineffective at suppressing aphids when in the presence of other natural enemies (Rosenheim et al., 1993). Despite these interactions which complicate our understanding of the ability of natural enemies in biological control, there is sufficient evidence to suggest that the assemblage of generalist predators can contribute towards pest reduction (Symondson et al., 2002) and has been supported by mathematical modelling which predicts that control is only likely early in the season (Fleming, 1980), before colonization by specialist natural enemies.

For these reasons, whereby interactions between natural enemies can be additive, synergistic or detrimental to biological control, careful assessment of the feeding ecology of generalist predators is required before they can be implicated for pest management. Numerous techniques have assessed this impact, all of which make certain assumptions and have interpretative complications. Gutcontent analyses allow prey consumption to be assessed after the feeding event (or events) occurred naturally in the field and will be reviewed with reference to aphidophagous predators. Potential sources of error inherent to gut-content analyses, which are regularly ignored in field studies, will be outlined in detail. Other methods of biocontrol evaluation (laboratory trials, manipulative experiments and direct observations) will be discussed briefly, 
describing the difficulties of correlating their results to natural interactions in the field.

\section{DIRECT OBSERVATIONS AND MANIPULATIVE EXPERIMENTS}

Determining the biocontrol potential of aphidophagous predators cannot follow protocols which can be applied across species and habitats. Often subtle differences in the biology and behaviour of predators may allow certain techniques to accurately assess biological control by some arthropods but not others. Whilst certain forms of gutcontent analysis can be utilized to study the feeding activity of all predators (discussed in detail below), observations and manipulations of predator and prey communities have been used extensively to estimate the role of some natural enemies in biological control.

\section{Direct observations}

The observation of feeding behaviour has been used to gather valuable information on the spectrum of prey captured and feeding frequencies, but does not allow accurate estimates of predation in the field. For example, direct observations have indicated that the diet of webbuilding spiders is dominated by homopteran prey (Nyffeler, 1999). However, these techniques sometimes yield fewer than one feeding observation per person hour (Nyffeler, 1999) and are complicated by partial consumption and/or rejection of prey, resulting in the overestimation of predation rates upon less-preferred prey. Therefore, direct observations only provide preliminary information on prey taken by predators in the field.

Directly observing predation using video analysis (Schenk \& Bacher, 2002) provides more accurate information on feeding behaviour in the field and can monitor day and night-time (using infra-red light) activity. Although the positioning of a camera in the field poses some technical challenges, it is extremely effective at monitoring the consumption of prey and attack behaviour of predators with less selectivity and greater accuracy than visual observations which are susceptible to human error and bias. For example, Schenk \& Bacher (2002) deduced that the paper wasp Polistes dominulus (Christ) (Hymenoptera: Vespidae) was the primary predator of Cassida rubiginosa Müller (Coleoptera: Chrysomelidae) and that predation occurred exclusively during the day. Video technology clearly allows accurate assessment of attack rates in the field and the spectrum of prey consumed. These approaches are most effective with those predators feeding on small, cryptic and immobile prey items where visual identification is difficult.

\section{Laboratory experiments}

Laboratory experiments usually fail to replicate all variables experienced by predators in the field. Even within large-scale controlled environment facilities where it is often possible to accurately study complex interactions, certain assumptions have to be made and with mobile aphidophagous predators it is difficult to simulate all these interactions. Despite these difficulties, laboratory trials do enable the breakdown of ecological, behavioural and trophic connections within invertebrate food webs. Ultimately, they can implicate species as valuable biological control agents and formulate hypotheses which can be tested with quantitative studies in the field.

Given that many aphidophagous predators exhibit generalist feeding habits, laboratory trials can indicate differential acceptabilities of prey, which can be used to record the availability of "potential prey" in the field (Harwood et al., 2001a, 2003) and model pest consumption rates (Harwood et al., 2004). During trials that evaluate feeding behaviour, it is important to consider that simple laboratory arenas do not represent the complex field environment in which a predator's decision to attack may be different. They can only be viewed as establishing whether or not a predator is capable of killing and consuming particular prey. Toft (1997) reported that aversions were acquired by wolf spiders exposed to an aphid-only diet whilst Greenstone (1979) suggested that these aphidophagous predators optimized their dietary intake of essential amino acids which could lead to the rejection of certain prey, although the likelihood of such discrimination in the field is low given that food items are often in short supply. Despite the artificial environment, laboratory studies can provide valuable information on prey acceptability and prey quality. In parallel with field studies, they form a basis for determining the role of aphidophagous predators in biological control.

\section{Caged and manipulative field experiments}

Caged experiments allow the manipulation of predator and prey densities, enabling biocontrol efficiencies to be evaluated. They often provide a more realistic habitat than laboratory environments and allow the assessment of interactions between natural enemies which are sometimes (Snyder \& Ives, 2001) but not always (Colfer \& Rosenheim, 2001) detrimental to pest control. For example, Colfer \& Rosenheim (2001) reported that within parasitoid-only control plots, rates of parasitism never exceeded $10 \%$ but rather than reducing biological control due to between-species competition, the addition of predator communities further suppressed aphid densities despite high levels of predation on immature parasitoids. However, care is needed during the implementation of caged experiments to ensure comparable conditions and interactions to those experienced in the field. Despite these difficulties, caged field experiments allow specific hypotheses to be tested under "field" conditions, which are not possible in the laboratory.

Ultimately all observatory and manipulative studies can, if they are carefully designed and the results interpreted accurately, provide information on the behaviour and ecology of aphidophagous predators. If performed in parallel to gut-content analysis and population monitoring, the results can be additive and allow an increasingly accurate determination of the role of natural enemies in biological control.

\section{GUT-CONTENT ANALYSIS}

The ability to identify prey remains within arthropod predators is essential for understanding the trophic inter- 
actions within complex food webs. This is especially important in generalist predators whose biocontrol potential can sometimes be affected by the presence of alternative prey (Madsen et al., 2004). Advantageous to observatory and manipulative experiments, results can be obtained from systems where predation occurred naturally without experimental interference. The application of post-mortem analyses to studying predation has been reviewed (Boreham \& Ohiagu, 1978; Sunderland, 1988, 1996; Greenstone, 1996; Solomon et al., 1996; Symondson, 2002a) and analyzed in relation to specific predators (Greenstone, 1999; Symondson, 2002b) or prey (Obrycki, 1992; Symondson \& Liddell, 1996). The effectiveness of different techniques varies between predators and/or prey, thus each trophic connection being examined should be considered as a separate parameter. For example, faecal analysis enables prey DNA or proteins to be measured but collecting such material from aphidophagous predators may be difficult. Many aphidophagous predators also feed by liquid ingestion making gut dissection redundant. It is therefore important to evaluate the relevance of each technique in terms of the prey item being consumed (aphid body parts may enable visual identification of remains) and the predator consuming target material.

The application of gut-content analyses have evolved from simple dissection and visual identification of prey, first reported in carabids and coccinellids in the $19^{\text {th }}$ Century (Forbes, 1883), to highly sophisticated techniques utilizing the identification of species-specific prey DNA using multiplex-PCR (Harper et al., 2005) or prey epitopes using monoclonal antibodies (Symondson et al., 1996; Harwood et al., 2004, 2005). Despite the progression of new technologies, all techniques have associated strengths and weaknesses which influence interpretation of results and will be discussed in detail.

Despite these technical and interpretative difficulties, over 100 studies have used gut-content analysis to assess aphid predation (Table 1). It is interesting to note that predation by carabids is well documented (Fig. 1) but other voracious aphid predators have been poorly studied, possibly due to the ease of capture (by pitfall trapping) of

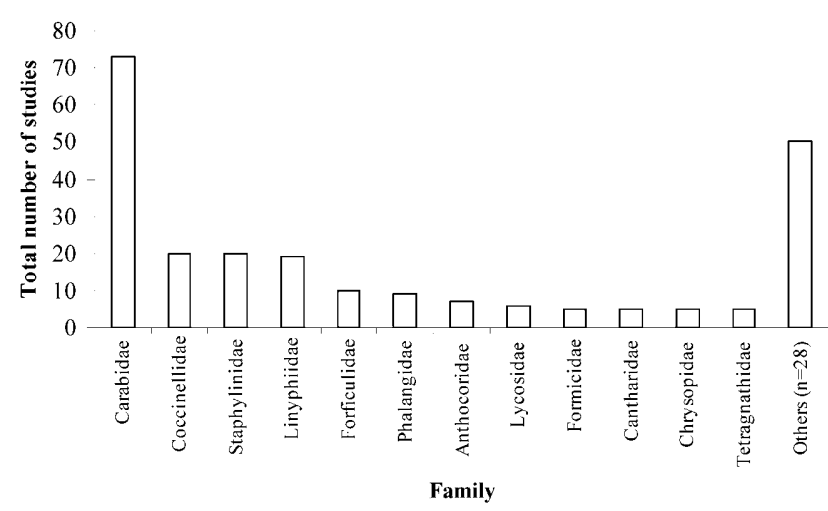

Fig. 1. Number of studies investigating the feeding behaviour of aphidophagous predators using gut-content or analytical analyses. Twelve families are presented separately; the remaining twenty-eight families were represented by fewer than five studies and are categorized as "Others". these epigeal predators. This demonstrates the need for a wider evaluation of predator communities, all of which feed on aphids and potentially impact their densities.

\section{Gut dissection}

Although many aphidophagous predators feed by liquid ingestion, certain species consume particulate matter which allows examination of remains from the digestive tract or gut of a predator. Providing sufficient taxonomic skills enable accurate identification, the simplicity of these techniques explains why they have been widely utilized for analyzing gut-contents of carabids, coccinellids, Opiliones and dermapterans (Table 1). Gut dissection was first employed to assess aphid predation in the $19^{\text {th }}$ Century (Forbes, 1883) and was still used, albeit less frequently, until the end of the $20^{\text {th }}$ Century (e.g. Holland \& Thomas, 1997; Triltsch, 1999).

Despite its application to over $50 \%$ of studies measuring aphid predation by gut-content analysis, there are many interpretative complications. It is extremely difficult to quantify prey consumption from solid remains within a predators gut. Although possible to identify some structures belonging to Aphididae, such as antennae, cornicles, legs, cauda and (if alate) wing remains, determining the number (or biomass) of aphids consumed is problematic due to differential rates of digestion of body parts. Species-level identification of these partially degraded structures also requires great taxonomic skill. Dixon \& McKinlay (1992) analyzed the gut content of 1800 Pterostichus melanarius (Illiger) (Coleoptera: Carabidae) and 910 P. madidus (F.) (Coleoptera: Carabidae) from commercial potato crops and indicated that, respectively, $14.1 \%$ and $30.5 \%$ contained aphids, of which $80 \%$ were Macrosiphum euphorbiae (Thomas) (Hemiptera: Aphididae). However, the vast majority of studies categorize predation as "aphid-consumption", making little or no attempt to differentiate among species. In addition, many aphidophagous predators feed by liquid ingestion and exhibit extra-oral digestion. In such instances, gut dissection would provide no information on prey consumption other than the extent to which the gut is filled with partially digested and liquefied prey. Nevertheless, where prey can be identified, gut dissection can provide an inexpensive and easily applied alternative to the more complex biochemical and molecular techniques.

\section{Faecal analysis}

In recent years, molecular technology has allowed the accurate identification of prey remains within faecal samples of vertebrate predators (e.g. Jarman et al., 2004), but is difficult to apply to invertebrate predator-prey systems. However, Pallant (1969) collected faeces of the grey field slug $A$. reticulatum from leaves of dicotyledonous herbs in British woodland and identified indigested and partially decayed material evacuated from the gut. Although dominated by plant remains, arthropod fragments (aphid exoskeleton, earthworm chaete and dipteran wings) were recorded in $21.2 \%$ of slugs. 
TABLE 1. Laboratory and field investigations employing the use of post-mortem gut-content and analytical analyses to measure (or develop methods to measure) predation and digestion rates of aphidophagous invertebrate predators.

\begin{tabular}{|c|c|c|c|c|}
\hline Predator(s) ${ }^{1}$ & Target(s) ${ }^{2}$ & Techniques $^{3}$ & ${\text { Habitat}(s)^{4}}^{4}$ & Reference \\
\hline Cara, Cocc & Aphididae & Dissect & Var & Forbes (1883) \\
\hline Cocc, Salt, Syrp & Anuraphis spp. & Radio-lab & $\mathrm{Fl}$ & Pendleton \& Grundmann (1954) \\
\hline Cara & Aphididae & Dissect & $\mathrm{Ar}$ & Skuhravý (1959) \\
\hline Phal & Microlophium spp. & Faecal & $\mathrm{Lab}$ & Phillipson (1960) \\
\hline Forf & Aphididae & Dissect & $\mathrm{Ar}$ & Skuhravý (1960) \\
\hline Anth & A. spartii & Pc/TbPrecip & $\mathrm{Fl}$ & Dempster (1963) \\
\hline Cocc & Aphididae & Dissect & Fr & Putman (1964) \\
\hline Cara & Aphididae & Dissect & Fn & Dawson (1965) \\
\hline Cara & Aphididae & Dissect & Wd & Penney (1966) \\
\hline Cocc & Aphididae & Dissect & Wd & Eastop \& Pope (1969) \\
\hline Lima & Aphididae & Dissect/Faecal & Wd & Pallant (1969) \\
\hline Cara, Phal & Aphididae & Dissect & $\mathrm{V}$ & Foster (1970) \\
\hline Anth, Cara, Cocc, Chry, Syrp & R. padi & $\mathrm{Pc} / \mathrm{IEF}, \mathrm{Ouch}$ & $\mathrm{Lab}$ & Pettersson (1972) \\
\hline Cara & Aphididae & Dissect & Fr & Cornic (1973) \\
\hline Agri & M. persicae & Dissect & $\mathrm{SgB}$ & Fox \& Landis (1973) \\
\hline Cara & Aphididae & Dissect & $\mathrm{Gr}, \mathrm{Fr}$ & Luff (1974) \\
\hline Cara, Forf, Heni, Stap & Aphididae & Dissect & SB, WW & Sunderland (1975) \\
\hline Cant, Cara, Club, Cocc, Forf, Stap, Syrp & Aphididae & $\mathrm{Pc} / \mathrm{Ouch}$ & $\mathrm{SB}, \mathrm{WW}$ & Vickerman \& Sunderland (1975) \\
\hline Anth & R. insertum & GelElec & Lab & Murray \& Solomon (1978) \\
\hline Cocc & A. pisum & Immuno/LatexAgg & $\mathrm{Lab}$ & Ohiagu \& Boreham (1978) \\
\hline Cara & Aphididae & Dissect & $\mathrm{Ht}, \mathrm{Gr}$ & Hengeveld (1980) \\
\hline Cara, Cocc, Forf, Stap & Aphididae & Dissect & $\mathrm{SB}, \mathrm{WW}$ & Sunderland \& Vickerman (1980) \\
\hline Cara & Aphididae & Dissect & $\mathrm{SgB}, \mathrm{WW}$ & Gregoire-Wibo (1982) \\
\hline Cara & Aphididae & Dissect & $\mathrm{Lab}$ & Griffiths (1982) \\
\hline Cara & M. viciae, M. persicae & Immuno/Ouch & $\mathrm{Ar}$ & Hance \& Gregoire-Wibo (1983) \\
\hline Cara & M. viciae, M. persicae & Immuno/Ouch & $\mathrm{Lab}$ & Hance \& Rossignol (1983) \\
\hline Sisy & Aphididae & Dissect & Fr, Cy & Kokubu \& Duelli (1983) \\
\hline Cara & Aphididae & Dissect & $\mathrm{Wd}$ & Loreau (1983a) \\
\hline Cara & Aphididae & Dissect & $\mathrm{Wd}$ & Loreau (1983b) \\
\hline Cara & Aphididae & Dissect & $\mathrm{Ar}$ & Loughridge \& Luff (1983) \\
\hline Cara & R. padi & Dissect & SB & Chiverton (1984) \\
\hline $\begin{array}{l}\text { Anth, Cara, Club, Empi, Forf, Form, } \\
\text { Leio, Liny, Lith, Lyco, Meso, Stap, Tetr }\end{array}$ & Aphididae & Immuno/dabELISA & Lab & Crook \& Sunderland (1984) \\
\hline Cara & A. fabae & Immuno/dabELISA & $\mathrm{Lab}$ & Hance \& Tries (1984) \\
\hline Cara & Aphididae & Dissect & $\mathrm{Wd}$ & Koehler (1984) \\
\hline Cocc, Heme, Lyco, Nabi, Phal & Acyrthosiphon spp. & Pc/Precip & Luc & Leathwick \& Winterbourn (1984) \\
\hline Cara & Aphididae & Dissect & $\mathrm{Wd}$ & Loreau (1984) \\
\hline Cara & Aphididae & Dissect & SB & Scheller (1984) \\
\hline $\begin{array}{l}\text { Anyp, Anys, Aran, Cara, Chry, Club, } \\
\text { Cocc, Empi, Heme, Liny, Meti, Miri, } \\
\text { Nabi, Phal, Proc, Redu, Stap, Syrp, Ther }\end{array}$ & Homoptera & $\mathrm{Pc} / \mathrm{Ouch}$ & Wd & Turner (1984) \\
\hline Cara & Aphididae & Dissect & Gr & Desender \& Pollet (1985) \\
\hline Cara & Aphididae & Dissect & WW & Griffiths et al. (1985) \\
\hline Cara & Aphididae & Dissect & $\mathrm{Gr}$ & Pollet \& Desender (1985) \\
\hline Cara, Stap & Aphididae & Dissect & WW & Coombes (1986) \\
\hline Cocc & Aphididae & Faecal & $\mathrm{X}$ & Honek (1986) \\
\hline Stap & Aphididae & Dissect & WW, SB, Gr & Kennedy et al. (1986) \\
\hline Osmy & Aphididae & Dissect & Rip & Kokubu \& Duelli (1986) \\
\hline Cocc & 5 species of aphid & Dissect & WW, SB & Ricci (1986) \\
\hline $\begin{array}{l}\text { Cant, Cara, Liny, Lyco, Forf, Form, } \\
\text { Phal, Stap }\end{array}$ & R. padi & Immuno/dabELISA & SB & Chiverton (1987a) \\
\hline Cara & R. padi & Dissect & SB & Chiverton (1987a) \\
\hline $\begin{array}{l}\text { Cant, Cara, Forf, Form, Liny, Lyco, } \\
\text { Phal, Stap }\end{array}$ & R. padi & Pc/dabELISA & SB & Chiverton (1987b) \\
\hline Cara & A. fabae & Immuno/indELISA & $\mathrm{SgB}$ & Hance \& Renier (1987) \\
\hline Cara & S. avenae & Immuno/dabELISA & Lab & Lövei et al. (1987) \\
\hline Forf & Aphididae & Dissect & $\mathrm{Wd}$ & Nielsen (1987) \\
\hline Cara & Aphididae & Dissect & Gr & Pollet \& Desender (1987a) \\
\hline Cara & Aphididae & Dissect & $\mathrm{Gr}$ & Pollet \& Desender (1987b) \\
\hline Cara & Aphididae & Dissect & $\mathrm{Gr}$ & Pollet et al. (1987) \\
\hline Cara, Liny, Stap, Tetr & Aphididae & Pc/dabELISA & WW & Sopp \& Chiverton (1987) \\
\hline $\begin{array}{l}\text { Anth, Aran, Cant, Cara, Club, Empi, } \\
\text { Forf, Form, Leio, Liny, Lioc, Lyco, } \\
\text { Miri, Nabi, Para, Phal, Scat, Stap, Tetr, } \\
\text { Ther, Thom }\end{array}$ & Aphididae & Pc/dabELISA & WW & Sunderland et al. (1987) \\
\hline Stap & M. dirhodum & GelElec & WW & Good \& Giller (1988) \\
\hline
\end{tabular}




\begin{tabular}{|c|c|c|c|c|}
\hline Cara & Aphididae & Dissect & WW & Janssens \& De Clercq (1988) \\
\hline Cara & Aphididae & Dissect & $\mathrm{Gr}$ & Pollet \& Desender (1988) \\
\hline Cara, Liny & Aphididae & Pc/dabELISA & $\mathrm{Ce}$ & Burn (1989) \\
\hline Phal & M. euphorbiae, M. persicae & Dissect & $\mathrm{V}$ & Dixon \& McKinlay (1989) \\
\hline Dict & A. pomi & ImmElec & $\mathrm{Fr}$ & Hagley \& Allen (1989) \\
\hline Cara & Aphididae & Dissect & $\mathrm{V}$ & Kabacik-Wasylik (1989) \\
\hline Cara, Liny, Stap & S. avenae & Immuno/dabELISA & $\mathrm{Lab}$ & Sopp \& Sunderland (1989) \\
\hline Cara & Aphididae & Dissect & $\mathrm{Gr}$ & Bruinink (1990) \\
\hline \multicolumn{2}{|c|}{ Cara, Chry, Cocc, Forf, Form, Miri, Redi A. pomi } & $\mathrm{Pc} / \mathrm{ImmElec}$ & $\mathrm{Fr}$ & Hagley \& Allen (1990) \\
\hline Cara, Stap & Aphididae & Pc/dabELISA & WW & Janssens \& De Clercq (1990) \\
\hline Cara & Aphididae & Dissect & WW & Janssens \& De Clercq (1990) \\
\hline Cara, Stap & S. avenae & Pc/dabELISA & $\mathrm{Lab}$ & Lövei et al. (1990) \\
\hline Cara & Aphididae & Dissect & $\mathrm{Gr}$ & Pollet \& Desender (1990) \\
\hline Cara & Aphididae & Dissect & SW & Chiverton \& Sotherton (1991) \\
\hline Stap & Aphididae & Dissect & SW & Dennis et al. (1991) \\
\hline Cara & Aphididae & Dissect & $\mathrm{Ce}$ & Burn (1992) \\
\hline Cara, Liny & Aphididae & Pc/dabELISA & $\mathrm{Ce}$ & Burn (1992) \\
\hline Cara & M. euphorbiae, M. persicae & Dissect & $\mathrm{V}$ & Dixon \& McKinlay (1992) \\
\hline Cara & R. padi & Dissect & SB & Holopainen \& Helenius (1992) \\
\hline Cara, Liny, Stap & S. avenae & Pc/dabELISA & Lab & Sopp et al. (1992) \\
\hline Anys, Meso & S. avenae & GelElec & WW & El Banhawy et al. (1993) \\
\hline Cara, Cocc & A. pisum & Dissect & $\mathrm{A}, \mathrm{Cl}, \mathrm{P}$ & Ekbom (1994) \\
\hline Cant, Nabi & Aphididae & Immuno/dabELISA & WW & Löbner \& Hartwig (1994) \\
\hline Cara, Liny, Stap & S. avenae & Pc/dabELISA & WW & Winder et al. (1994) \\
\hline Cara, Liny & S. avenae & SI & Lab & Nienstedt \& Poehling (1995) \\
\hline Cocc & A. idaei & SI & $\mathrm{Fr}$ & Scrimgeour et al. (1995) \\
\hline Cara & Aphididae & Dissect & \multicolumn{2}{|c|}{ BW, Fr, SB, GrSunderland et al. (1995) } \\
\hline Cara & Aphididae & Dissect & WW & Holland et al. (1996) \\
\hline Cara & Aphididae & Dissect & Rip & Hering \& Plachter (1997) \\
\hline Cara & Aphididae & Dissect & WW & Holland \& Thomas (1997) \\
\hline Cocc & Aphididae & SI & A, Lab & Ostrom et al. (1997) \\
\hline Cocc & Aphididiae & Dissect & WW & Triltsch (1997) \\
\hline Anth & R. maidis & GelElec & $\mathrm{Cn}$ & Corey et al. (1998) \\
\hline Cara & Aphididae & Dissect & Rip & Hering (1998) \\
\hline Cara & S. avenae & SI & $\mathrm{Lab}$ & Nienstedt \& Poehling (1998) \\
\hline $\mathrm{Cocc}$ & Aphididae & Dissect & WW & Triltsch (1999) \\
\hline Cara & Aphididae & MAb/indELISA & $\mathrm{Lab}$ & Symondson et al. (1999a) \\
\hline Chry, Cocc & R. maidis, $R$. padi & DNA/PCR & $\mathrm{Lab}$ & Chen et al. (2000) \\
\hline Cara, Liny & S. avenae & SI & $\mathrm{Lab}$ & Nienstedt \& Poehling (2000) \\
\hline Chry & A. gossypii & Pc/dabELISA & $\mathrm{Ct}$ & Su et al. (2000) \\
\hline Cara, Liny & S. avenae & MAb/indELISA & $\mathrm{Lab}$ & Harwood et al. (2001b) \\
\hline Liny & Aphididae & MAb/indELISA & WW & Harwood et al. (2001c) \\
\hline Anys & R. insertum & DNA/PCR & $\mathrm{Lab}$ & Cuthbertson et al. (2003) \\
\hline Oxyo & R. maidis, $R$. padi & DNA/PCR & $\mathrm{Lab}$ & Greenstone \& Shufran (2003) \\
\hline Cocc & A. gossypii & SI & Ct, So, Lab & Prasifka et al. (2004) \\
\hline Liny & Aphididae & MAb/indELISA & WW & Harwood et al. (2004) \\
\hline Anyp & M. caryaefoliae & Pc/indELISA & Pec & Renouard et al. (2004) \\
\hline Tetr & Aphididae & MAb/indELISA & WW & Harwood et al. (2005) \\
\hline Cara & Aphididae & MAb/indELISA & WW & Winder et al. (2005) \\
\hline Cara & 6 species of aphid & DNA/PCR & Lab, Sbn, W & Harper et al. (2005) \\
\hline
\end{tabular}

${ }^{1}$ Predators categorized to family-level: Agri, Agriolimacidae (Mollusca); Anth, Anthocoridae (Hemiptera); Anyp, Anyphaenidae (Araneae); Anys, Anystidae (Acari); Aran, Araneidae (Araneae); Cant, Cantharidae (Coleoptera); Cara, Carabidae (Coleoptera); Chry, Chrysopidae (Neuroptera); Club, Clubionidae (Araneae); Cocc, Coccinellidae (Coleoptera); Dict, Dictynidae (Araneae); Empi, Empididae (Diptera); Forf, Forficulidae (Dermaptera); Form, Formicidae (Hymenoptera); Heme, Hemerobiidae (Neuroptera); Heni, Henicopidae (Lithobiomorpha); Leio, Leiodidae (Coleoptera); Lima, Limacidae (Mollusca); Liny, Linyphiidae (Araneae); Lioc, Liocranidae (Araneae); Lith, Lithobiidae (Chilopoda); Lyco, Lycosidae (Araneae); Meso, Mesostigma (Acari); Meti, Metidae (Araneae); Miri, Miridae (Hemiptera); Nabi, Nabidae (Hemiptera); Osmy, Osmylidae (Neuroptera); Oxyo, Oxyopidae (Araneae); Para, Parasitidae (Acari); Phal, Phalangiidae (Opiliones); Proc, Proctotrupidae (Hymenoptera); Redu, Reduviidae (Heteroptera); Scat, Scathophagidae (Diptera); Sisy, Sisyridae (Neuroptera); Stap, Staphylinidae (Coleoptera); Syrp, Syrphidae (Diptera); Tetr, Tetragnathidae (Araneae); Ther, Theriidae (Araneae); Thom, Thomisidae (Araneae).

${ }^{2}$ where aphids were identified to species level these are noted, otherwise categorized as Aphididae when consumption on precise species were not recorded.

${ }^{3}$ Abbreviations used in Techniques: dabELISA, double-antibody sandwich enzyme-linked immunosorbent assay; Dissect, gut dissection; DNA, DNA-based technique; Faecal, analysis of faecal samples; GelElec, gel electrophoresis; indELISA, indirect enzyme-linked immunosorbent assay; IEF, Isoelectric focusing; ImmElec, Immunoelectrophoresis on cellulose acetate membranes; Immuno, immunoglobulin; LatexAgg, Latex Agglutination; MAb, monoclonal antibody; Ouch, Ouchterlony test; Pc, polyclonal antibody; PCR, polymerase chain reaction; Precip, precipitin test; Radio-Lab, recovery of radiolabelled prey; SI, stable isotope analysis; TbPrecip, Tube Precipitin test.

${ }^{4}$ Habitat in which study was undertaken: A, alfalfa; Ar, arable fields (precise crop not recorded); BW, buckwheat; Ce, cereals; $\mathrm{Cl}$, clover; Cn, corn; Ct, cotton; Cy, City/urban habitat; Fl, flowing plants; Fn, fenland habitat; Fr, fruit/orchards; Gr, grassland; Ht, heathland; Lab, laboratory study; Luc, lucerne; Ms, marshland; P, peas; Pec, pecan; Rip, riparian; SB, spring barley; SBn, spring bean; SgB, sugar-beet; So, sorghum; SW, spring wheat; V, vegetables; Var, various and mixed habitats; Wd, woodland/forest; WW, winter wheat; X, unspecified. 
Importantly, the dissection of faeces and visual identification of remains cannot quantify direct levels of predation in the field. The data provides qualitative information on recognizable prey passing through the digestive system, but not on quantities consumed.

\section{Radio-isotope labelling}

The labelling of prey or plant material with radioactive isotopes or elements such as rubidium can be used to track trophic movements in food webs. Although the labelling of aphids with radioactive phosphorous has indicated the extent of its uptake by parasitoids (Robertson, 1976) and the dispersal of virulous aphids in sugar beet (Bjorling et al., 1951), there is only one study documenting its application for quantifying aphid predation (Pendleton \& Grundman, 1954). The thistle Cirsium undulatum (Nutt.) Spreng. (Asterales: Asteraceae) was inoculated with ${ }^{32} \mathrm{P}$ which was taken up by aphids within the genus Anuraphis. Extrapolating from counts per million of ${ }^{32} \mathrm{P}$ within aphids to its presence in predators, Pendleton \& Grundman (1954) semi-quantitatively estimated the number of aphids consumed by spiders, coccinellids and syrphids. Notwithstanding the ability of this technique to suggest that Diptera larvae were the most important aphid predator on thistle, such methods are fraught with potential error. Whilst they implicate trophic links, the likelihood of false positives from scavenging on contaminated material and secondary predation by feeding on other predators which contain radio-labelled prey, are high. Furthermore, environmental concerns, regulations and ethical issues relating to the field-release of radio-labelled material are the most powerful reasons which explain why such techniques are rarely used to study predator-prey interactions.

\section{Stable isotopes}

It is also possible to measure the ratio of stable isotopes, most frequently $\delta^{15} \mathrm{~N}$ and $\delta^{13} \mathrm{C}$, within predators using mass spectrometry (Table 1), but they are rarely utilized to study trophic interactions between aphidophagous predators and prey (Scrimgeour et al., 1995; Prasifka et al., 2004). One reason for their sparse representation is the relative expense of equipment and technical expertise required to analyze samples even though screening protocols are inexpensive compared with biochemical or molecular techniques.

Measuring the feeding behaviour of Hippodamia convergens Guérin-Méneville (Coleoptera: Coccinellidae), Prasifka et al. (2004) collected predators from cotton by aspirator and screened them for ${ }^{13} \mathrm{C}:{ }^{12} \mathrm{C}$ ratios using combustion - gas chromatography - mass spectrometry. Within the laboratory it was possible to observe changes in isotopic ratio when these predators switched from feeding on a $\mathrm{C}_{4}$-based diet [Aphis gossypii Glover (Hemiptera: Aphididae) reared on grain sorghum] to a $\mathrm{C}_{3}$-based diet (A. gossypii reared on cotton), with ratios stabilizing after 3 days. Although at intermediate periods and during the dietary mixing of prey in the field it may be difficult to accurately determine the food source, Prasifka et al. (2004) deduced that during times of low aphid abundance, $H$. convergens rarely fed on non-aphid food which had originated from cotton. During high aphid densities in cotton, isotopic ratios were comparable to laboratory studies of individuals feeding on an exclusively $\mathrm{C}_{3}$-based diet indicating significant predation upon pests within these fields.

However, when determining the role of a predator in biological control, it is necessary to measure how much material has been eaten. The tracking of stable isotope ratios within food chains can only reveal qualitative information on trophic links, making it difficult to assess the biocontrol efficiency of predators. There is also a lack of information available on detection periods for stable isotope ratios and the rates at which the proportions present in the predators gut fragment at different temperatures, during dietary mixing and at variable hunger levels. Although this preliminary characterization is required, with careful consideration of potential errors, stable isotopes could prove useful in future food-web studies.

\section{Electrophoresis}

The electrophoretic analysis of prey isoenzymes offers an alternative approach to quantitative biochemical and molecular applications (Solomon et al., 1996). First demonstrated in the laboratory for studying predation of Rhopalosiphum insertum (Walker) (Hemiptera: Aphididae) (Murray \& Solomon, 1978) and subsequently utilized in the field (Good \& Giller, 1988; Corey et al., 1998), electrophoresis enables the rapid screening of invertebrates without the complex development procedures associated with antibody and DNA-based approaches. Although care is required when designing a system capable of separating prey enzymes into highly focussed bands, once optimized the preparation and running of gels follows a relatively simple and standardized protocol.

Good \& Giller (1988) attempted to measure $\alpha$-esterase and malate dehydrogenase enzyme patterns of Metopolophium dirhodum (Walker) (Hemiptera: Aphididae) and Sminthurus viridis (Lubbock) (Collembola: Sminthuridae) within Tachyporus hypnorum (F.) (Coleoptera: Staphylinidae). Although it had been possible to separate esterase enzymes in the past (Murray \& Solomon, 1978; Giller, 1986), they were unable to distinguish between species, concluding that esterases were unsuitable because of intraspecific variation within the staphylinid predators and their prey. However, even if prey enzymes were separated, the use of vacuum suction sampling invalidated the results due to surface-level contamination and increased likelihood of false-positive reactivity (discussed below). More acceptable were the techniques of Corey et al. (1998) who, by cutting whole plants and sealing in bags prior to transfer into a freezer, minimized surface-level contamination. Targeting isocitrate dehydrogenase, Corey et al. (1998) separated multiple prey enzymes on polyacrylamide gels and measured predation upon Rhopalosiphum maidis (Fitch) (Hemiptera: Aphididae) by Orius insidiosus (Say) (Hemiptera: Anthocoridae) in corn. It was possible to separate the banding patterns of seven prey items, but they only reported the proportion of predators screening positive. However, providing charac- 
terization of the electrophoretic system is undertaken it is possible to correlate the intensity of stain to the concentration of target enzyme in the sample, thus allowing accurate quantification of prey material within the predator.

Electrophoretic analysis could provide a less-expensive alternative to antibody and DNA-based techniques. If the gel and enzyme system can be optimized to ensure that banding patterns can be distinguished, the wide availability of electrophoretic equipment in laboratories could be advantageous, in some cases, for studying predatorprey systems. Indeed, Solomon et al. (1996) concluded that these techniques were valuable in predation studies, especially where multiple prey are consumed.

\section{Chromatography}

The detection of prey pigments by gas chromatography has been used to determine the diet of marine organisms and high-pressure liquid chromatography has measured levels of glucosinolate sequestration by arthropods, but only occasionally have these techniques been used to study aphid predation (Table 1). Putman (1969) distinguished between predation upon two different mites by spiders in peach orchards using paper chromatography but the separation of pigments was not complete and accurate identification proved impossible. This was further complicated by the presence of multiple prey within predator guts and the difficulties of quantification. Given these limitations, the application of chromatographic techniques for quantifying generalist predator diets is unlikely.

\section{Serological techniques}

For nearly 60 years, antibodies have been developed in vertebrate hosts to enable the study of predator feeding habits. These systems have been reviewed extensively with new technologies continually providing more complex and accurate assays (Boreham \& Ohiagu, 1978; Sunderland, 1988, 1996; Greenstone, 1996; Symondson, 2002a, b). Given the extensive literature already available on earlier serological techniques, this review will concentrate on the use of polyclonal and monoclonal antibodies in quantitative assays for predator-prey analysis.

It is theoretically possible to produce antisera against any species but in many cases limited sensitivity and specificity is achieved. Hundreds of studies have developed polyclonal antisera to scrutinize interactions between predators and prey, with assays being capable of quantitatively detecting prey remains by colorimetric determination. Presently, the most commonly employed immunoassay techniques are the indirect ELISA, dotblot assay and double-antibody sandwich ELISA. The most sensitive ELISA for detecting target prey in predator guts is the indirect ELISA (Crook \& Payne, 1980) but the double-antibody sandwich assay tends to be less susceptible to non-specific binding due to the attachment of antibodies to two target sites. Other studies have also reported that the dotblot assay tends to be more sensitive than conventional ELISA (Stuart \& Greenstone, 1990; Hagler et al., 1995). Therefore, dependent upon the assay requirements, i.e. whether greater sensitivity or specificity is required, different methodologies can be designed to improve the detection of target prey. Boreham \& Ohiagu (1978) commented that the major disadvantage of precipitin tests were their relative insensitivity to the remains of partially degraded prey, but these technical difficulties have been overcome as ELISA's are highly sensitive to the presence of extremely small quantities of target material.

The development of polyclonal antisera generally involves the immunization of vertebrates with target prey to generate an immune response. However, ELISA's are highly sensitive and antisera often cross-react with proteins common across species (Harwood et al., 1999b; Renouard et al., 2004). It is therefore important to test antisera against non-target species prior to the screening of field-collected predators to ensure accurate interpretation of trophic links, and if the specificity is sufficiently low, it can be improved by absorbing against cross reacting material or antibody purification by affinity chromatography. Despite their simple preparation, polyclonal antisera have determined aphid predation by many predators in the field (Table 1). In a survey of over 7,500 predators, Sunderland et al. (1987) developed digestion rate and predation indices (to account for the variable detection limits between species) to assess the biocontrol potential of predators. Spiders, dominated by the Linyphiidae, were the principle aphid predators but mass screening also implicated nine other Orders as important predators. Although the results were semi-quantitative (percentage of predators testing positive), current ELISA technology allows the concentration and quantity of target prey to be determined. Providing extensive characterization is undertaken, polyclonal antisera could still offer a considerably less expensive alternative to monoclonal or DNA-based techniques. However, due to the crude nature of their design, specificity cannot be assured and even when it is achieved sensitivity is sometimes compromised such that prey remains are undetectable in predator guts.

Monoclonal antibodies overcome this lack of specificity but are technically challenging to develop, considerably more expensive and time consuming to achieve a suitable monoclone. Their development follows the protocol initially described by Köhler \& Milstein (1979) who reported that when B lymphocytes were fused with myeloma cells, antibody-producing hybridomas were created. These produced a monoclone of identical antibodyproducing cells that bound to a single target epitope. Dependent upon the extent to which this epitope exists across species, stages or instars, highly specific antibodies can be produced in limitless supply. This high degree of specificity can be achieved by the careful selection of antibody-secreting hybridoma cell lines, resulting in their extensive application to study predation in the field (Table 1).

Despite the specificity that can be achieved, the high cost of monoclonal production and characterization (Chen et al., 2000), high equipment costs and technical complexities associated with their development often make 
the use of such quantitative systems beyond the limits of many ecological studies. However, they are a powerful tool for studying predation in the field and their long detection period improves the likelihood of detecting prey consumption. Following characterization of an anti-aphid monoclonal antibody, Harwood et al. (2004) measured predation rates of linyphiid spiders in winter wheat and tracked the effect of alternative prey on consumption rates. Although high rates of aphid consumption were recorded, Collembola (an important non-pest food resource) influenced predation rates of erigonid spiders, thus reducing levels of biological control. Similar tracking of predator and prey populations were reported by Winder et al. (2005) who correlated the activity and spatial patterns of carabids with those of their prey. These simultaneous assessments of prey availability and quantitative measures of predation are essential to enhancing our understanding of the complex trophic interactions between predators and prey. Symondson (2002a) commented that monoclonal antibodies are the most accurate molecular technique available for studying predation in the field. Although developmental success is not assured (Chen et al., 2000) and extensive characterization is required, it is their flexibility, ease of quantitative screening and the ability to screen samples rapidly against single prey is likely to result in their continued application when studying trophic connections in the field.

\section{Molecular techniques}

Until recently, antibody-based approaches have been the method of choice for quantifying predation and measuring trophic links within food webs. The proliferation of molecular technology opens up exciting new challenges, enabling the detection of species-specific DNA sequences within predator guts.

Molecular markers have been utilized in entomology for many years (Loxdale \& Lushai, 1998) but only recently have DNA-based approaches been applied to study invertebrate predation in the field (Agustí et al., 2003; Harper et al. 2005). However, this is likely to change in light of the numerous laboratory studies which have demonstrated the ability to detect DNA remains within predator guts (Zaidi et al., 1999; Chen et al., 2000; Hoogendoorn \& Heimpel, 2001; Cuthbertson et al., 2003; Grenstone \& Shufran, 2003; Sheppard et al., 2004). In principle, molecular techniques could be applied to almost any predator-prey system and would be especially useful in generalist predators where a multitude of prey species are likely to be present within the gut. The application of multiplex-PCR's to separate species (Hinamoto et al., 2004) and its ability to simultaneously amplify degraded mitochondrial DNA of different prey (Harper et al., 2005) implicate these molecular techniques as having distinct advantages to biochemical analyses which have, to date, relied on running multiple assays against each target prey.

Agustí et al. (2003) designed primers to amplify fragments of the mitochondrial cytochrome oxidase subunit I gene to detect predation by linyphiid spiders on six species of Collembola in winter wheat. Following characteri- zation of the primer system, spiders were collected and guts amplified by polymerase chain reaction. It was possible to show that these spiders preferentially consumed Isotoma anglicana Lubbock (Collembola: Isotomidae), a prey item that was relatively scarce in the field. In a different approach using the mitochondrial 16S rDNA gene, Kasper et al. (2004) compared the feeding behaviour of a native and an introduced social wasp by analyzing the content of masticated food samples. It was found that the native Polistes humilis (F.) (Hymenoptera: Vespidae) fed almost exclusively upon lepidopteran larvae but the introduced Vespula germanica (F.) (Hymenoptera: Vespidae) had a rather more generalist feeding habit, with its masticated food sample containing both vertebrate (chicken and kangaroo) and invertebrate (Araneae, Coleoptera, Diptera, Hemiptera, Hymenoptera, Neuroptera, Odonata and Orthoptera) prey, which included Symydobius kabae Matsumura (Hemiptera: Aphididae). The collection of such data from field populations of introduced species allows for risk assessments to be made, especially between those individuals whose niches overlap.

These studies demonstrate the value of molecular techniques but, like other forms of gut-content analysis, have complications associated with their interpretation. To date, molecular approaches have resulted in relatively short detection periods of prey DNA (e.g. Zaidi et al., 1999; Agustí et al., 2003; Greenstone \& Shufran, 2003; Sheppard et al., 2004) compared to the slow breakdown of prey antigens detectable by monoclonal antibodies (Symondson et al., 1999a; Harwood et al., 2001c, 2004; Schenk \& Bacher, 2004). This shortened detection therefore reduces the likelihood of determining positive feeding events and trophic links in the field. Despite these shorter detection times, Agustí et al. (2003) was able to document significant levels of predation in the field and Kaspar et al. (2004) recorded a range of prey in decayed and macerated food samples. However, the fast decay rates of DNA may hinder studies within agroecosystems especially upon less common prey. Furthermore, the dietary mixing of prey by generalist predators may (or may not) influence the rate at which partially digested prey (and decayed DNA) breaks down. The use of shorter DNA base pair sequences (Zaidi et al., 1999; Agustí et al., 2003) have increased detection periods but molecular methods have not, as yet, allowed the quantification of prey remains within predator guts although real-time PCR is likely to make this possible and allows rapid, sensitive, cost-effective and quantitative measurements of target DNA. Its application to invertebrate predator-prey systems is likely and will provide a viable alternative to quantitative immunological detection systems.

Although questions remain (notably the detection of scavenged material in predator guts, potential food chain errors, the role of feeding on alternative prey, maximizing the short detection periods and quantifying DNA material within guts), molecular techniques exhibit great potential for use in quantifying trophic interactions and breaking down complex food webs in the field. The principle concern for the use of DNA technology are the short detec- 
tion periods that may limit the detectability of prey, although these are not sufficiently rapid to prevent the detection of scavenged material in predator guts (Juen \& Traugott, 2005), a situation also evident in antibodybased assays (Calder et al., 2005). The application of molecular techniques to measure predation in the field is only likely to increase with the continual development and application of new molecular systems to invertebrate food webs (e.g. multiplex-PCR, RFLP-analysis, DNA cloning and sequencing, temperature or denaturing gradient gel electrophoresis, and competitive sequence analysis). However, further system characterization is required and should precede field-based analyses to identify sources of error and determine detection limits. Without such characterization, it may be difficult to determine trophic links in the field.

\section{PROBLEMS OF QUANTIFYING PREDATION USING GUT-CONTENT ANALYSES}

Gut-content analysis can provide a valuable insight into the feeding ecology and trophic interactions between aphidophagous predators and their prey, but to measure direct predation, a number of prerequisites must be satisfied. Despite the requirement for pre-screening of assays and techniques, many studies assessing gut-content incorrectly attribute the presence of prey remains to direct predation in the field.

\section{Methods of predator collection}

Prior to screening, invertebrate samples must be collected from the field which can lead to inaccuracies of interpretation. Vacuum suction sampling and sweep netting enable the rapid collection of predators but can invalidate estimates of predation due of the likelihood for "false-positives" from surface-level contamination with prey (Crook \& Sunderland, 1984). Despite this error, predators are frequently assayed for predation following sweep netting (e.g. Leathwick \& Winterbourn, 1984; Löbner \& Hartwig, 1994) and D-Vac (e.g. Good \& Giller, 1988). If the guts are extracted (or predators washed), the number of false-positives may be reduced but preanalysis characterization would be necessary to ensure direct levels of predation were not overestimated due to interactions with target prey within the sweep net or D-Vac.

Pitfall trapping overcomes the problems of contamination, has been used to trap generalist predators for gutcontent analysis and has the benefit of measuring the activity-density of predator communities. Although external contamination is eliminated, direct predation can occur within dry pitfalls if prey aggregate to such environments. Within a carabid-slug system, Symondson et al. (1996) concluded that the error caused by carabid predation upon slugs was negligible since the pitfalls were unattractive to these prey. Although suitable for certain predator-prey systems, it is therefore necessary to evaluate potential sources of error prior to implementing sampling programmes. Pitfall traps can also be filled with alcohol or a dilute detergent solution which has little effect on the detectability of prey material within predator guts (Crook \& Sunderland, 1984) but may attract invertebrates which contaminate the trapping substance that is subsequently imbibed by predators during death.

Surrounding plants with bags before transferring predators to a freezer has been used to measure predation rates in the field (Corey et al., 1998) but inherent with such techniques are the possibilities of actively increasing the interactions between predators and prey in the bag. The delay of $2 \mathrm{~h}$ before Corey et al. (1998) transferred predators to a refrigerator, before being frozen, could allow direct predation, thus increasing the proportion of predators screening positive.

The most accurate means of collecting predators from the field is by aspirator and rapid freezing of samples (Harwood et al., 2004, 2005; Prasifka et al., 2004). Although unsuitable for certain predators, this method allows easy collection of aphidophagous predators such as spiders and coccinellids without the possibility of overestimating predation due to sampling inefficiencies. The principle problem is that they represent a very timeconsuming form of predator collection but guarantee errors-of-predation are not due to incorrect sampling protocols. An alternative to this time-consuming collection technique is the sampling of arthropod predators from underneath small wooden planks placed in the field (Bilde \& Toft, 1998). This yields a large number of generalist predators that have not been removed from their natural habitat (Søren Toft, pers. commun.) and can be collected for gut-content analysis.

\section{Scavenging}

The presence of prey within a gut only indicates that the target has been consumed. Scavenging can seriously overestimate direct predation rates of field-collected predators and falsely implicate them as valuable biocontrol agents. Spiders usually rely on active movement to stimulate attack response behaviour and therefore overestimating "true" predation due to scavenging is unlikely. More important are the scavenging activities of Opiliones, Carabidae, Coccinellidae and Dermaptera which can imply "true" predation, especially given that some predators preferentially feed on freshly killed rather than live prey (Mair \& Port, 2001). Despite this significant source of error, Sunderland (1996) reported that of 72 publications using antibodies to measure predation between 1956 and 1994, only 15\% considered scavenging as a source of error but none quantified its significance. This is extremely significant given that within a carabidslug system using monoclonal antibodies, Calder et al. (2005) reported the decay of target antigens on the soil surface was very slow and as a result scavenged material was detectable after $6 \mathrm{~h}$ digestion leading to the potential for inaccurate predation estimates in field collected carabids. Similarly with PCR-based techniques, Juen \& Traugott (2005) indicated the likelihood of inadvertently overestimating predation due to scavenging. Prior to the measurement of gut-content from field-collected predators, it is therefore essential that quantitative experiments are undertaken with the specific systems being used to 
quantify potential errors of overestimating "true" predation caused by scavenging.

\section{Secondary predation}

The inherent problem of many generalist aphidophagous predators is that in addition to feeding upon aphids and other herbivorous insects, many are cannibalistic and/or feed on other predators which may have consumed aphids. Although such behaviour is cited as a potential source of error in quantitative predator-prey systems using analytical techniques (Hagler \& Naranjo, 1996; Sunderland, 1996), only one study (Harwood et al., 2001b) has quantified its significance. This study indicated the likelihood of errors caused by secondary predation due to the carabid Poecilus cupreus (L.) (Coleoptera: Carabidae) feeding on spiders, Tenuiphantes tenuis (F.) (Araneae: Linyphiidae), that had consumed $S$. avenae when using an aphid-specific monoclonal antibody, was negligible. Given the extremely long detection period of this antibody and that aphid material could only be detected in carabids that were frozen immediately after they had consumed at least two spiders which themselves recently consumed significant quantities of aphid, indicated that such errors are unlikely in the field. The potential error within DNA-based detection systems is likely to be low (due to more rapid breakdown of DNA targets) but other analytical approaches could lead to sources of error. It is therefore essential that prior to alternative techniques being used on field-collected predators (including DNA-based methods where detection is unlikely, but possible) potential errors from secondary predation are quantitatively assessed in the laboratory.

\section{Between-species comparisons}

It is often valuable to compare feeding rates between different predators and prey. Direct comparisons enable a profile of predator communities to be compiled but interpretation can be difficult given that rates of antigen and DNA decay can sometimes (Symondson \& Liddell, 1993; Chen et al., 2000; Harwood et al., 2001b) but not always (Harwood et al., 2004, 2005) vary between species. This is further complicated by differences that can occur between males and females; Symondson et al. (1999b) reported that slug antigens within the male carabid $P$. melanarius were detectable for $30 \%$ longer than in females. If between-species or between-gender differences are observed in the laboratory, simple calibratory models should be developed to account for the variable rates of decay. In the absence of characterization, between-species comparisons are difficult to interpret and the presence of prey material in the gut of one predator does not imply it has a greater potential for pest regulation than another. For example, the longer detection periods of spiders compared to carabids (Harwood et al., 2001b) could result in higher prey concentrations within field-collected specimens due to physiological adaptations and not differences in feeding behaviour. It is also important to correlate predation rates with the availability of prey to each predator; coccinellids feed on aphids at a different stratum to spiders which intercept aphids in their webs when they fall to the ground. Aphids are finally exposed to carabids and other epigeal predators. The microhabitat to which each predator locates will therefore influence prey availability, and should be considered when assessing predation rates in the field.

\section{Correlating gut-content to predation rates}

Some of the most challenging aspects of gut-content analysis relate to the difficulties of correlating the presence of target prey to rates of predation. Currently, it is not possible to separate a large meal eaten some time ago (which has partially decayed in the gut) to a small meal eaten recently. Both situations can provide the same quantitative and/or qualitative result. Sunderland (1996) reported that the differential rates of antigenic decline exhibited by different monoclonal antibodies could enable the separation of these factors by screening predators against multiple assays. However, in practice such separation would be difficult given the multitude of complicating issues including partial consumption, repeated feeding on prey, variable handling times, wasteful killing and that gut samples of aphidophagous predators are usually contaminated with alternative food.

Naranjo \& Hagler (2001) incorporated aspects of feeding behaviour into a model with the percentage of predators testing positive to a species-specific monoclonal antibody. Although the percentage positive approach does not in itself enable gut-content to be quantified, this model highlights the potential for such techniques to determine predation rates from prey material within a gut sample. Despite the problems of linking gutcontent to actual rates of predation, a quantitative assay does represent an accurate means by which trophic links can be established and the biocontrol of a predator (or group of predators) estimated.

\section{Other considerations for gut-content analyses}

Many factors affecting prey detection have been assessed in antibody-based systems but they are equally applicable to other detection systems. The rate at which prey material decays can change with varying temperature, level of starvation, feeding on alternative prey (although this is not always the case) and meal size (reviewed by Sunderland, 1996). The screening of predators subjected to these varying conditions should therefore precede field-based analyses; otherwise conclusions on trophic links that exist and the biocontrol potential of generalist aphidophagous predators are not reliable. Laboratory decay rate experiments easily account for these variables and should be conducted at temperatures comparable to those in the field. Antigen or DNA decay rate experiments should consider that the guts of generalist predators are frequently in a state of semi-starvation and therefore the long-term ad libitum supply of prey (frequently provided in laboratory trials) may not accurately represent feeding parameters in the field. Although laboratory conditions cannot accurately replicate all biotic and abiotic conditions, careful selection of these criteria can allow the characterization of an assay which can validate its application to field-collected predators. 
The screening of predators can provide information on prey consumption but does not quantify the biocontrol potential of a generalist predator community. To make such conclusions, it is necessary to simultaneously monitor predator and prey population densities to model the impact of predator communities on aphid populations. For example, an increased aphid density may lead to increased predation by aphidophagous predators but the impact of these generalists is only likely early in the season (Chiverton, 1987a; Landis \& Van der Werf, 1997). Thus, the temporal monitoring of aphid (and predator) populations, and subsequent gut analysis, can provide an indication of whether predators are feeding on pests at the time when control is required.

\section{CONCLUSIONS}

Identifying prey remains within the guts of aphidophagous predators allows complex trophic interactions between generalist predator communities and their prey to be broken down from undisturbed, unmanipulated systems. Whilst aphids are clearly consumed by many species of predator, determining the extent to which such prey is consumed in relation to its availability is essential if we are to fully understand the biocontrol potential of natural enemy populations.

Observations of predation, manipulative field studies and feeding trials in the laboratory provide information on the feeding behaviour of predators but may not account for the many interactions that occur between arthropods in the field. Although gut-content analyses have difficulties associated with their interpretation, quantification and potential sources of error, they do represent an extremely accurate means by which the feeding behaviour of aphidophagous predators can be assessed. Over time, these techniques have become increasingly complex, allowing accurate species-specific assessments of prey consumption (monoclonal antibodies and DNAbased techniques requiring expensive equipment and extensive characterization presently represent the most frequently utilized technology). The choice of technique will sometimes be a compromise between utilizing the most accurate and quantifiable methodology (which tend to be the most complex and expensive) with methodological and financial constraints often limiting the ecological evaluation of invertebrate feeding behaviour and food web dynamics in low-value agricultural systems. Gut dissection and the visual identification of prey remains within invertebrates that feed on particulate matter has been the most widespread technique over the past century. It represents an inexpensive, semiquantitative measure of gut content and is still widespread today. For example, Woodward \& Hildrew (2002) were able to deduce that the six predatory species in their system consumed virtually every animal taxon smaller than themselves. Despite their simple approach, gut dissection and the visual identification of prey allows trophic interactions to be quantified and will have a significant role in the future. Perhaps the most powerful application of such techniques would be during preliminary evalua- tion of feeding behaviours in the field when the financial cost of alternative molecular or immunological technologies could prove prohibitively expensive. Stable isotopes may also offer a viable alternative as they have considerably lower costs compared to monoclonal and DNAbased approaches but further characterization of these systems are required before complex food webs can be constructed.

Symondson (2002a) commented that based on experimental evidence in the laboratory, PCR-based methodologies "are likely to rapidly displace all other approaches". In certain instances this will undoubtedly be the case, especially where multiple prey are to be detected and multiplex PCR's can allow the detection of prey DNA sequences simultaneously (Harper et al., 2005). However, certain methodological difficulties remain. Monoclonal antibodies are long-established techniques for quantifying predation and provide stable, replicable results and a limitless supply of antibody. They are the most accurate means by which field-collected predators can be assayed and the use of ELISA enables the mass screening of large numbers of predators (often in their thousands) which can be tested against individual prey species. The lower and faster development cost of species-specific DNA sequences compared to monoclonal antibodies (Chen et al., 2000) is invaluable when screening predators against a diverse range of prey but the rapid decay of DNA relative to protein epitopes could seriously hinder their advance. Expanding this detection limit, the development of quantitative real-time PCR systems and extensive laboratory characterization (which are essential and seriously lacking in DNA-based detection systems) could further swing the balance towards molecular- as opposed to antibody-based technology. However, if predation by large numbers of predators on a limited number of prey species is desired, especially if monoclonal antibodies have already been developed and characterized, these biochemical approaches will continue to have a valuable application in predation studies. Although the trade-off between the two techniques will continue, they appear likely to, in parallel, further enhance our understanding of the trophic interactions between predators and their prey in the field.

The most important considerations to be addressed before any technique can be applied to the field are the significant and potentially invalidating errors caused by inaccurate and/or insufficient characterization of the detection system. Carefully considering these potential sources of error allows all forms of gut-content analysis (gut dissection followed by visual identification, stable isotope analysis, electrophoresis, antibody technologies and detection of species-specific DNA) to provide valuable insights into the feeding ecology of predators in terrestrial, freshwater and marine ecosystems. Without consideration, inaccurate trophic links may be implicated, predation rates over- (or under-) estimated and, in terms of biological control, incorrect integrated pest management strategies implemented. 
ACKNOWLEDGEMENTS. The authors would like to thank $\mathrm{S}$. Toft (Aarhus University, Denmark) and A. Honěk (Research Institute of Crop Production, Czech Republic) for invaluable comments on an earlier draft. We are grateful to the University of Kentucky and College of Agriculture for providing financial support to JDH and JJO. This is publication number 04-08-137 of the University of Kentucky Agricultural Experiment Station.

\section{REFERENCES}

Agustí N., Shayler S.P., Harwood J.D., Vaughan I.P., SunderLAND K.D. \& SyMONDSON W.O.C. 2003: Collembola as alternative prey sustaining spiders in arable ecosystems: prey detection within predators using molecular markers. Mol. Ecol. 12: 3467-3475.

BiLde T. \& TofT S. 1998: Quantifying food limitation of arthropod predators in the field. Oecologia 115: 54-58.

BILdE T. \& TofT S. 2001: The value of three aphid species as a food for a generalist predator. Physiol. Entomol. 26: 58-68.

Bilde T., Axelsen J.A. \& Toft S. 2000: The value of Collembola from agricultural soils as food for a generalist predator. J. Appl. Ecol. 37: 672-683.

Bjorling K., LinNell D. \& Ossiannilsson F. 1951: Marking viruliferous aphids with radioactive phosphorous. Acta Agric. Scand. 1: 301-317.

Boreham P.F.L. \& Ohiagu C.E. 1978: The use of serology in evaluating invertebrate predator-prey relationships: a review. Bull. Entomol. Res. 68: 171-194.

BRUININK P.J. 1990: Some notes on the diet of the groundbeetle Pterostichus versicolor Sturm (Coleoptera, Carabidae). Pol. Pis. Entomol. 60: 153-166.

BuRN A.J. 1989: Long-term effects of pesticides on natural enemies of cereal crop pests. In Jepson P. (ed.): Pesticides and Non-Target Invertebrates. Intercept Press, Wimbourne, Dorset, pp. 177-193.

BURN A.J. 1992: Interactions between cereal pests and their predators and parasites. In Greig-Smith P., Frampton G. \& Hardy T. (eds): Pesticides, Cereal Farming and the Environment. The Boxworth Project. HMSO, London, pp. 110-131.

Calder C.R., Harwood J.D. \& SyMOndson W.O.C. 2005: Analysis of potential error caused by scavenging in generalist predators when detecting predation using monoclonal antibodies. Bull. Entomol. Res. 95: 57-62.

Chang G.C. \& Kareiva P. 1999: The case for indigenous generalists in biological control. In Hawkins B.A. \& Cornell H.C. (eds): Theoretical Approaches to Biological Control. Cambridge University Press, Cambridge, pp. 103-115.

Chen Y., Giles K.L., Payton M.E. \& Greenstone M.H. 2000: Identifying key cereal aphid predators by molecular gut analysis. Mol. Ecol. 9: 1887-1898.

Chiverton P.A. 1984: Pitfall trap catches of the carabid beetle Pterostichus melanarius, in relation to gut contents and prey densities, in insecticide treated and untreated spring barley. Entomol. Exp. Appl. 36: 23-30.

Chiverton P.A. 1987a: Predation of Rhopalosiphum padi (Homoptera: Aphididae) by polyphagous predatory arthropods during the aphids' pre-peak period in spring barley. Ann. Appl. Biol. 111: 257-269.

Chiverton P.A. 1987b: Predation on the Bird Cherry-Oat Aphid in Cereals. Ph.D. Thesis, Swedish University of Agricultural Sciences, Uppsala, Sweden.

Chiverton P.A. \& Sotherton N.W. 1991: The effects of beneficial arthropods of the exclusion of herbicides from cereal crop edges. J. Appl. Ecol. 28: 1027-1039.
Colfer R.G. \& Rosenheim J.A. 2001: Predation on immature parasitoids and its impact on aphid suppression. Oecologia 126: 292-304.

COOMBES D.S. 1986: The predatory potential of polyphagous predators in cereals in relation to timing of dispersal and aphid feeding. In Hodek I. (ed.): Ecology of Aphidophaga. Academia, Prague, pp. 429-434.

Corey D., Kambhampati S. \& Wilde G.E. 1998: Electrophoretic analysis of Orius insidiosus (Hemiptera: Anthocoridae) feeding habits in field corn. J. Kans. Entomol. Soc. 71: 11-17.

CoRNIC J.F. 1973: Étude du régime alimentaire de trois espèces de carabidiques et de ses variations en verger de pommiers. Ann. Soc. Entomol. Fr. 9: 69-87.

Crook N.E. \& PAYNe C.C. 1980: Comparison of three methods of ELISA for baculoviruses. J. Gen. Virol. 46: 29-37.

Crook N.E. \& Sunderland K.D. 1984: Detection of aphid remains in predatory insects and spiders by ELISA. Ann. Appl. Biol. 105: 413-422.

Cuthbertson A.G.S., Fleming C.C. \& Murchie A.K. 2003: Detection of Rhopalosiphum insertum (apple-grass aphid) predation by the predatory mite Anystis baccarum using molecular gut analysis. Agric. Forest Entomol. 5: 219-225.

Dawson N. 1965: A comparative study of the ecology of eight species of fenland Carabidae (Coleoptera). J. Anim. Ecol. 34: 299-314.

Dempster J.P. 1963: The natural prey of three species of Anthocoris (Heteroptera: Anthocoridae) living on broom (Sarothamnus scoparius L.). Entomol. Exp. Appl. 7: 149-154.

Dennis P., Wratten S.D. \& Sotherton N.W. 1991: Mycophagy as a factor limiting predation of aphids (Hemiptera, Aphididae) by staphylinid beetles (Coleoptera, Staphylinidae) in cereals. Bull. Entomol. Res. 81: 25-31.

Desender K. \& Pollet M. 1985: Ecological data on Clivinia fossor (Coleoptera, Carabidae) from a pasture ecosystem. II. Reproduction, biometry, biomass, wing polymorphism and feeding ecology. Rev. Écol. Biol. Sol 22: 233-246.

DiXon P.L. \& McKinlay R.G. 1989: Aphid predation by harvestmen in potato fields in Scotland. J. Arachnol. 17: 253-255.

Dixon P.L. \& McKinlay R.G. 1992: Pitfall trap catches and aphid predation by Pterostichus melanarius and Pterostichus madidus in insecticide treated and untreated potatoes. Entomol. Exp. Appl. 64: 63-72.

Eastop V.F. \& Pope R.D. 1969: Notes on the biology of some British Coccinellidae. Entomologist 102: 162-164.

Еквом В. 1994: Arthropod predators of the pea aphid Acyrthosiphon pisum (Hom., Aphididae) in peas (Pisum sativum L.), clover (Trifolium pratense L.) and alfalfa (Medicago sativa L.). J. Appl. Entomol. 117: 469-476.

El Banhawy E.M., Carter N. \& Wynne I.R. 1993: Preliminary observations on the population development of anystid and free-living mesostigmatic mites in a cereal field in southern England. Exp. Appl. Acarol. 17: 541-549.

Evans E.W. 2004: Habitat displacement of North American ladybirds by an introduced species. Ecology 85: 637-647.

FLEMING R.A. 1980: The potential for control of cereal rust by natural enemies. Theor. Popul. Biol. 18: 374-395.

ForBES S.A. 1883: The food relations of the Carabidae and Coccinellidae. Bull. Illinois St. Lab. Nat. Hist. 1: 33-64.

Foster G.N. 1970: Natural enemies of Bourletiella hortensis (Fitch) (Collembola). Entomol. Mon. Mag. 106: 96.

GILLER P. 1986: The natural diet of the Notonectidae: field trials using electrophoresis. Ecol. Entomol. 11: 163-172. 
Good J.A. \& GILLER P.S. 1988: Impact of crop management on staphylinid diet variability: a preliminary evaluation of electrophoretic prey detection. Ecol. Bull. 39: 94-96.

GreEnstone M.H. 1979: Spider feeding behaviour optimises dietary essential amino acid composition. Nature 282: 501-503.

GREENSTONE M.H. 1996: Serological analysis of arthropod predation: past, present and future. In Symondson W.O.C. \& Liddell J.E. (eds): The Ecology of Agricultural Pests. Chapman \& Hall, London, pp. 265-300.

GreEnstone M.H. 1999: Spider predation: how and why we study it. J. Arachnol. 27: 333-342.

Greenstone M.H. \& Shufran K.A. 2003: Spider predation: species-specific identification of gut contents by polymerase chain reaction. J. Arachnol. 31: 131-134.

Gregoire-Wibo C. 1982: Ecologie de Loricera pilicornis F. (Coleoptera, Carabidae) en culture. Med. Fac. Landbouww. Rijksuniv. Gent 47: 729-739.

Griffiths E. 1982: The carabid Agonum dorsale as a predator in cereals. Ann. Appl. Biol. 101: 152-154.

Griffiths E., Wratten S.D. \& Vickerman G.P. 1985: Foraging by the carabid Agonum dorsale in the field. Ecol. Entomol. 10: $181-189$.

Hagler J.R. \& Cohen A.C. 1990: Effects of time and temperature on digestion of purified antigen by Geocoris punctipes (Hemiptera: Lygaeidae) reared on artificial diet. Ann. Entomol. Soc. Am. 83: 1177-1180.

HAGLER J.R. \& NARANJo S.E. 1994: Qualitative survey of two coleopteran predators of Bemisia tabaci (Homoptera: Aleyrodidae) and Pectinophora gossypiella (Lepidoptera: Gelechiidae) using a multiple prey gut content ELISA. Environ. Entomol. 23: 193-197.

Hagler J.R. \& NARANJo S.E. 1996: Using gut content immunoassays to evaluate predaceous biological control agents: a case study. In Symondson W.O.C. \& Liddell J.E. (eds): The Ecology of Agricultural Pests. Chapman \& Hall, London, pp. 383-399.

Hagler J.R., Buchman S.L. \& Hagler D.A. 1995: A simple method to quantify dot blots for predator gut analyses. $J$. Entomol. Sci. 30: 95-98.

Hagley E.A.C. \& Allen W.R. 1989: Prey of the cribellate spider, Dictyna annulipes (Araneae, Dictynidae), on apple tree foliage. J. Arachnol. 17: 366-367.

Hagley E.A.C. \& Allen W.R. 1990: The green aphid, Aphis pomi DeGeer (Homoptera: Aphididae), as prey of polyphagous arthropod predators in Ontario. Can. Entomol. 122: $1221-1228$

Hance T. \& GrÉGOIRe-Wibo C. 1983: Étude du régime alimentaire des Carabidae par voie sérologique. In Lebrun P., André H., De Medts A., Grégoire-Wibo C. \& Wauthy G. (eds): New Trends In Soil Biology. Imprimerie Dieu-Brichart, OttigniesLouvain, Belgium, pp. 620-622.

Hance T. \& Renier L. 1987: An ELISA technique for the study of the food of carabids. Acta Phytopath. Entomol. Hung. 22: 363-368.

Hance T. \& Rossignol R. 1983: Essai de quantification de la prédation des Carabidae par le test ELISA. Med. Fac. Landbouww. Rijksuniv. Gent 48: 475-485.

Hance T. \& Tries E. 1984: Appreciation du role de Omaseidius vulgare (Coleoptera: Carabidae) dans la limitation des populations de pucerons. Med. Fac. Landbouww. Rijksuniv. Gent 49: 849-855.

Hare M.P., Palumbi S.R. \& Butman C.A. 2000: Single-step species identification of bivalve larvae using multiplex polymerase chain reaction. Mar. Biol. 137: 953-961.
Harper G.L., King R.A., Dodd C.S., Harwood J.D., Glen D.M., BRUford M.W. \& Symondson W.O.C. 2005: Rapid screening of invertebrate predators for multiple prey DNA targets. Mol. Ecol. 14: 819-828.

Harwood J.D., Symondson W.O.C. \& Sunderland K.D. 1999: Antisera to detect predation on Collembola and Diptera. Antenna 23: 236-238.

Harwood J.D., Sunderland K.D. \& Symondson W.O.C. 2001a: Living where the food is: web location by linyphiid spiders in relation to prey availability in winter wheat. J. Appl. Ecol. 38: 88-99.

Harwood J.D., Phillips S.W., Sunderland K.D. \& Symondson W.O.C. 2001b: Secondary predation: quantification of food chain errors in an aphid-spider-carabid system using monoclonal antibodies. Mol. Ecol. 10: 2049-2057.

Harwood J.D., Sunderland K.D. \& Symondson W.O.C. 2001c: Monoclonal antibodies to quantify the effects of alternative prey on aphid predation by spiders. Antenna 25: 257-259.

Harwood J.D., Sunderland K.D. \& Symondson W.O.C. 2003: Web-location by linyphiid spiders: prey-specific aggregation and foraging strategies. J. Anim. Ecol. 72: 745-756.

Harwood J.D., Sunderland K.D. \& Symondson W.O.C. 2004: Prey selection by linyphiid spiders: molecular tracking of the effects of alternative prey on rates of aphid consumption in the field. Mol. Ecol. 13: 3549-3560.

Harwood J.D., Sunderland K.D. \& Symondson W.O.C. 2005: A quantitative assessment using monoclonal antibodies of the potential of the tetragnathids spider Pachygnatha degeeri to control aphids. Bull. Entomol. Res. 95: 161-167.

Hengeveld R. 1980: Polyphagy, oligophagy and food specialization in ground beetles (Coleoptera, Carabidae). Neth. J. Zool. 30: 564-584.

HeRING D. 1998: Riparian beetles (Coleoptera) along a small stream in the Oregon coast range and their interactions with the aquatic environment. Coleopts. Bull. 52: 161-170.

Hering D. \& Plachter H. 1997: Riparian ground beetles (Coleoptera, Carabidae) preying on aquatic invertebrates: a feeding strategy in alpine floodplains. Oecologia 111: 261-270.

Hinomoto N., Muraji M., Noda T., Shimiza T. \& Kawasaki K. 2004: Identification of five Orius species in Japan by multiplex polymerase chain reaction. Biol. Control 31: 276-279.

Holland J.M. \& Thomas S.R. 1997: Assessing the role of beneficial invertebrates in conventional and integrated farming systems during an outbreak of Sitobion avenae. Biol. Agric. Hort. 15: 73-82.

Holland J.M., Thomas S.R. \& Hewitt A. 1996: Some effects of polyphagous predators on an outbreak of cereal aphid (Sitobion avenae F.) and orange wheat blossom midge (Sitodiplosis mosellans Géhin). Agric. Ecosyst. Environ. 59: 181-190.

Holopainen J.K. \& Helenius J. 1992: Gut contents of ground beetles (Col., Carabidae), and activity of these and other epigeal predators during an outbreak of Rhopalosiphum padi (Hom., Aphididae). Acta Agric. Scand. (B, Soil Plant Sci.) 42: 57-61.

HoNĚK A. 1986: Production of faeces in natural populations of aphidophagous coccinellids (Col.) and estimation of predation rates. J. Appl. Entomol. 102: 467-476.

Hoogendoorn M. \& Heimpel G.E. 2001: PCR-based gut content analysis of insect predators: using ribosomal ITS-1 fragments from prey to estimate predation frequency. Mol. Ecol. 10: 2059-2068.

Hoogendoorn M. \& Heimpel G.E. 2004: Competitive interactions between an exotic and a native ladybeetle: a field cage study. Entomol. Exp. Appl. 111: 19-28. 
Janssens J. \& De Clerco R. 1988: Observations on the carabids Pterostichus melanarius (Illiger) and Platynus dorsalis (Pontoppidan) (Col., Carabidae) as predators of cereal aphids in winter wheat. Med. Fac. Landbouww. Rijksuniv. Gent 53: $1131-1136$

Janssens J. \& De Clerce R. 1990: Observations on Carabidae, Staphylinidae and Araneae as predators of cereal aphids in winter wheat. Med. Fac. Landbouww. Rijksuniv. Gent 55: 471-475.

Jarman S.N., Deagle B.E. \& Gales N.J. 2004: Group-specific polymerase chain reaction for DNA-based analysis of species diversity and identity in dietary samples. Mol. Ecol. 13: $1313-1322$.

Juen A. \& Traugott M. 2005: Detecting predation and scavenging by DNA gut-content analysis: a case study using a soil insect predator-prey system. Oecologia 142: 344-352.

KABACIK-WASYLIK D. 1989: The food of two Carabidae species in potato crops. Pol. Ecol. Stud. 15: 111-117.

Kaspar M.L., Reeson A.F., Cooper S.J.B., Perry K.D. \& Austin A.D. 2004: Assessment of prey overlap between a native (Polistes humilis) and an introduced (Vespula germanica) social wasp using morphology and phylogenetic analysis of 16S rDNA. Mol. Ecol. 13: 2037-2048.

Kennedy T.F., Evans G.O. \& Feeney A.M. 1986: Studies on the biology of Tachyporus hypnorum F. (Col.: Staphylinidae) associated with cereal fields in Ireland. Irish J. Agric. Res. 25: 81-95.

KoEHLER H. 1984: Zum Nahrungsspektrum und Nahrungsumsatz von Pterostichus oblongopunctatus und Pterostichus metallicus (Coleoptera, Carabidae) im Ökosystem, Buchenwald. Pedobiologia 27: 171-183.

KöHLeR G. \& Milstein C. 1975: Continuous culture of fused cells secreting antibody of predefined specificity. Nature $\mathbf{2 5 6}$ 495-497.

KoKuBu H. \& Duelli P. 1983: Adult food of sponge flies: observations on the crop and gut contents of Sisyra terminalis Curtis (Planipennia: Sisyridae). Neuropt. Int. 2: 157-162.

Kokubu H. \& Duelli P. 1986: Adult food of Osmylidae: intestinal contents of Osmylus fulvicephalus (Scopoli). In Gepp J., Aspöck H. \& Hölzel H. (eds): Recent Research in Neuropterology. Published by the editor, Graz, Austria, pp. 151-155.

LANDIS D.A. \& VAN DER WeRF W. 1997: Early-season predation impacts the establishment of aphids and spread of beet yellows virus in sugar beet. Entomophaga 42: 499-516.

Leathwick D.M. \& Winterbourn M.J. 1984: Arthropod predation on aphids in a Lucerne crop. N.Z. Entomol. 8: 75-80.

Löbner U. \& Hartwig O. 1994: Soldier beetles (Col., Cantharidae) and nabid bugs (Het., Nabidae) - occurrence and importance as aphidophagous predators in winter wheat fields in the surroundings of Halle/Saale (Sachsen-Anhalt). Bull. IOBC 17: 179-187.

LOREAU M. 1983a: Le régime alimentaire de Abax ater Vill. (Coleoptera, Carabidae). Acta Oecol.-Oec. Gen. 4: 253-263.

LOREAU M. 1983b: Le régime alimentaire de huit carabides (Coleoptera) communs en milieu forestier. Acta Oecol.-Oec. Gen. 4: 331-343.

LOREAU M. 1984: Les niches écologiques des Carabides en milieu forestier. II. Composante trophique et organization générale des niches. Acad. R. Belg. (Classe Sci.) 70: 480-525.

Loughridge A.H. \& LufF M.L. 1983: Aphid predation by Harpalus rufipes (Degeer) (Coleoptera: Carabidae) in the laboratory and field. J. Appl. Ecol. 20: 451-462.

LÖvei G.L., Sopp P. \& SunderLand K.D. 1987: The effect of mixed feeding on the digestion of the carabid Bembidion lampros. Acta Phytopathol. Entomol. Hung. 22: 403-407.
Lövei G.L., Sopp P.I. \& Sunderland K.D. 1990: Digestion rate in relation to alternative feeding in three species of polyphagous predators. Ecol. Entomol. 15: 293-300.

LOXDALE H.D. \& LUSHAI G. 1998: Molecular markers in entomology. Bull. Entomol. Res. 88: 577-600.

LufF M.L. 1974: Adult and larval feeding habits of Pterostichus madidus (F.) (Coleoptera: Carabidae). J. Nat. Hist. 8: 403-409.

Madsen M., Terkildsen S. \& Toft S. 2004: Microcosm studies on control of aphids by generalist arthropod predators: effects of alternative prey. BioControl 49: 483-504.

Mair J. \& Port G.R. 2001: Predation by the carabid beetles Pterostichus madidus and Nebria brevicollis is affected by the size and condition of the prey slug Deroceras reticulatum. Agric. Ecosyst. Environ. 3: 99-106.

Murdoch W.W., Chesson J. \& Chesson P.L. 1985: Biological control in theory and practice. Am. Nat. 125: 344-366.

Murphy M.A., Waits L.P. \& Kendall K.C. 2003: The influence of diet on faecal DNA amplification and sex identification in brown bears (Ursus arctos). Mol. Ecol. 12: 2261-2265.

Murray R.A. \& Solomon M.G. 1978: A rapid technique for analyzing diets of invertebrate predators by electrophoresis. Ann. Appl. Biol. 90: 7-10.

Naranjo S.E. \& Hagler J.R. 2001: Toward the quantification of predation with predator gut immunoassays: a new approach integrating functional response behavior. Biol. Control 20: $175-189$.

NIELSEN B.O. 1987: Skovørentvistens (Chelidurella acanthyopygia Géné) føde (Dermaptera: Forficulidae). [The food of Chelidurella acanthyopygia Géné (Dermaptera: Forficulidae).] Entomol. Medd. 54: 125-128 [in Danish, English abstr.].

Nienstedt K.M. \& Poehling H.M. 1995: Labelling aphids with ${ }^{15} \mathrm{~N}$ - an appropriate method to quantify the predation efficiency of polyphagous predators? Mitt. Dt. Ges. All. Angew. Entomol. 10: 227-230.

Nienstedt K.M. \& Poehling H.M. 1998: Using the stable isotope ${ }^{15} \mathrm{~N}$ as marker for analysis of the predatory efficiency of polyphagous predators against cereal aphids. Bull. OILBSROP/IOBCWPRS 21: 125-131.

Nienstedt K.M. \& Poehling H.M. 2000: ${ }^{15} \mathrm{~N}$-marked aphids for predation studies under field conditions. Entomol. Exp. Appl. 94: 319-323.

Nyffeler M. 1999: Pest selection of spiders in the field. $J$. Arachnol. 27: 317-324.

OBRYCKI J.J. 1992: Techniques for evaluation of predators of Homoptera. Fla Entomol. 75: 472-476.

Ohiagu C.E. \& Boreham P.F.L. 1978: A simple field test for evaluating insect prey-predator relationships. Entomol. Exp. Appl. 23: 40-47.

Ostrom P.H., Colunga-Garcia M. \& Gage S.H. 1997: Establishing pathways of energy flow for insect predators using stable isotope ratios: field and laboratory evidence. Oecologia 109: 108-113

Pallant D. 1969: The food of the grey field slug Agriolimax reticulatus (Müller) in woodland. J. Anim. Ecol. 38: 391-398.

Pendleton R.C. \& Grundmann A.W. 1954: Use of $\mathrm{P}^{32}$ in tracing some insect-plant relationships of the thistle Cirsium undulatum. Ecology 35: 187-191.

Penney M.M. 1966: Studies on certain aspects of the ecology of Nebria brevicollis (F.) (Coleoptera, Carabidae). J. Anim. Ecol. 35: 505-512.

Pettersson J. 1972: Technical description of a serological method for quantitative predator efficiency studies on Rhopalosiphum padi (L.). Swed. J. Agric. Res. 2: 65-69. 
Phillipson J. 1960: A contribution to the feeding biology of Mitopus morio (F.) (Phalangida). J. Anim. Ecol. 29: 35-43.

Pollet M. \& Desender K. 1985: Adult and larval feeding ecology in Pterostichus melanarius Ill. (Coleoptera, Carabidae). Med. Fac. Landbouww. Rijksuniv. Gent 50: 581-594.

Pollet M. \& Desender K. 1987a: The consequences of different life histories in ground beetles for their feeding ecology and impact on other pasture arthropods. Med. Fac. Landbouww. Rijksuniv. Gent 52: 179-190.

Pollet M. \& Desender K. 1987b: Feeding ecology of grassland inhabiting carabid beetles (Carabidae, Coleoptera) in relation to the availability of some prey groups. Acta Phytopath. Entomol. Hung. 22: 223-246.

Pollet M. \& Desender K. 1988: Quantification of prey uptake in pasture inhabiting carabid beetles. Med. Fac. Landbouww. Rijksuniv. Gent 53: 1119-1129.

Pollet M. \& Desender K. 1990: Investigating the food passage in Pterostichus melanarius (Coleoptera, Carabidae): an attempt to explain its feeding behaviour. Med. Fac. Landbouww. Rijksuniv. Gent 55: 527-540.

Pollet M., Desender K. \& Van Kerckvoorde M. 1987: Prey selection in Loricera pilicornis (Col., Carabidae). Acta Phytopath. Entomol. Hung. 22: 425-431.

PrasifKa J.R., Heinz K.M. \& Winemiller K.O. 2004: Crop colonization, feeding, and reproduction by the predatory beetle, Hippodamia convergens, as indicated by stable carbon isotope analysis. Ecol. Entomol. 29: 226-233.

Putman W.L. 1964: Occurrence and food of some Coccinellids (Coleoptera) in Ontario peach orchards. Can. Entomol. 96: 1149-1155.

Putman W.L. 1965: Paper chromatography to detect predation on mites. Can. Entomol. 97: 435-441.

Putman W.L. 1967: Prevalence of spiders and their importance as predators in Ontaria peach orchards. Can. Entomol. 99: $160-170$.

Renouard J.J., Creamer R. \& Richman D.B. 2004: Gut content analysis of the spider Hibana incursa (Araneae: Anyphaenidae) using serological methods. Southwest. Entomol. 29: 91-97.

RICCI C. 1986: Seasonal food preferences and behaviour of Rhizobius litura. In Hodek I. (ed.): Ecology of Aphidophaga. Academia, Prague, pp. 119-123.

RoBertson G. 1976: Marking aphids and their parasites with ${ }^{14} \mathrm{C}$ in field studies. Entomol. Exp. Appl. 19: 65-76.

Roger C., Coderre D., Vigneault C. \& Boivin G. 2001: Prey discrimination by a generalist coccinellid predator: effect of prey age or parasitism? Ecol. Entomol. 26: 163-172.

Rosenheim J.A., WiLhoit L.R. \& ARMer C.A. 1993: Influence of intraguild predation among generalist predators on the suppression of an herbivore population. Oecologia 96: 439-449.

Scheller H.V. 1984: The role of ground beetles (Carabidae) as predators on early populations of cereal aphids in spring barley. Z. Angew. Entomol. 97: 451-463.

SCHENK D. \& BACHER S. 2002: Functional response of a generalist insect predator to one of its prey species in the field. $J$. Anim. Ecol. 71: 524-531.

SCHENK D. \& BACHER S. 2004: Detection of shield beetle remains in predators using a monoclonal antibody. J. Appl. Entomol. 128: 273-278.

Scrimgeour C.M., Gordon S.C., Handley L.L. \& Woodford J.A.T. 1995: Trophic levels and anomalous $\delta^{15} \mathrm{~N}$ of insects on raspberry (Rubus idaeus L.). Isot. Environ. Health Stud. 31: $107-115$.
Settle W.H., Ariawan H., Astuti E.T., Cayhana W., Hakim A.L., Hindayana D., Lestari A.S. \& Sartanto P. 1996: Managing tropical rice pests through conservation of generalist natural enemies and alternative prey. Ecology 77: 1975-1988.

Sheppard S.K., Henneman M.L., Memmott J. \& Symondson W.O.C. 2004: Infiltration by alien predators into invertebrate food webs in Hawaii: a molecular approach. Mol. Ecol. 13: 2077-2088

SkUHRAvÝ V. 1959: Potrava polních střevlíkovitých. [Food of Carabidae in fields.] Acta Soc. Entomol. Cechoslov. 1: 1-18 (in Czech, German abstr.).

SkuHRAvÝ V. 1960: Die Nahrung des Ohrwurms (Forficula auricularia L.) in der Feldkulturen. Acta Soc. Entomol. Cechoslov. 4: 329-339.

SNYDER W.E. \& IvES A.R. 2001: Generalist predators disrupt biological control by a specialist parasitoid. Ecology 82: 705-716.

Solomon M.G., FitzGerald J.D. \& Murray R.A. 1996: Electrophoretic approaches to predator-prey interactions. In Symondson W.O.C. \& Liddell J.E. (eds): The Ecology of Agricultural Pests. Chapman \& Hall, London, pp. 457-468.

Sopp P.I. \& ChIVERTon P. 1987: Autumn predation of cereal aphids by polyphagous predators in Southern England: a "first look" using ELISA. Bull. IOBC 10: 103-108.

Sopp P.I. \& SunDERLAND K.D. 1989: Some factors affecting the detection period of aphid remains in predators using ELISA. Entomol. Exp. Appl. 51: 11-20.

Sopp P.I., Sunderland K.D., Fenlon J.S. \& Wratten S.D. 1992: An improved quantitative method for estimating invertebrate predation in the field using an enzyme-linked immunosorbent assay (ELISA). J. Appl. Ecol. 29: 295-302.

Stuart M.K. \& Greenstone M.H. 1990: Beyond ELISA: a rapid, sensitive, specific immunodot assay for the identification of predator stomach contents. Ann. Entomol. Soc. Am. 83: $1101-1107$.

Su J.-W., Sheng C.-F. \& Yang X.-K. 2000: Predation of the green lacewing, Chrysopa phyllochroma Wesmael on the cotton aphid, Aphis gossypii Glover: intraspecific interference and space heterogeneity. Acta Entomol. Sinica 42: 107-111.

SunDERLAND K.D. 1975: The diet of some predatory arthropods in cereal crops. J. Appl. Ecol. 12: 507-515.

SUNDERLAND K.D. 1988: Quantitative methods for detecting invertebrate predation occurring in the field. Ann. Appl. Biol. 112: 201-224.

SunDERLAND K.D. 1996: Progress in quantifying predation using antibody techniques. In Symondson W.O.C. \& Liddell J.E. (eds): The Ecology of Agricultural Pests. Chapman \& Hall, London, pp. 419-455.

Sunderland K.D. \& Vickerman G.P. 1980: Aphid feeding by some polyphagous predators in relation to aphid density in cereal fields. J. Appl. Ecol. 17: 389-396.

Sunderland K.D., Axelsen J.A., Dromph K., Freier B., Hemptinne J.-L., Holst N.H., Mols P.J.M., Petersen M.K., Powell W., Ruggle P., Triltsch H. \& Winder L. 1997: Pest control by a community of natural enemies. Acta Jutl. 72: 271-326.

Sunderland K.D., Crook N.E., Stacey D.L. \& Fuller B.J. 1987: A study of feeding by polyphagous predators on cereal aphids using ELISA and gut dissection. J. Appl. Ecol. 24: 907-933.

Sunderland K.D., Lövei G.L. \& Fenlon J.S. 1995: Diets and reproductive phenologies of the introduced ground beetles Harpalus affinis and Clivina australasiae (Coleoptera: Carabidae) in New Zealand. Austr. J. Zool. 43: 39-50. 
Symondson W.O.C. 2002a: Molecular identification of prey in predator diets. Mol. Ecol. 11: 627-641.

SyMONDSON W.O.C. 2002b: Diagnostic techniques for determining carabid diets. In Holland J.M. (ed.): The Agroecology of Carabid Beetles. Intercept, Andover, Hampshire, pp. 137-164.

Symondson W.O.C. \& LidDell J.E. 1993: Differential antigen decay rates during digestion of molluscan prey by carabid predators. Entomol. Exp. Appl. 69: 277-287.

SyMONDSON W.O.C. \& LidDell J.E. 1996: Polyclonal, monoclonal and engineered antibodies to investigate the role of predation in slug predation dynamics. In Symondson W.O.C. \& Liddell J.E. (eds): The Ecology of Agricultural Pests. Chapman \& Hall, London, pp. 323-366.

Symondson W.O.C., Glen D.M., Wiltshire C.W., Langdon C.J. \& LidDELl J.E. 1996: Effects of cultivation techniques and methods of straw disposal on predation by Pterostichus melanarius (Coleoptera: Carabidae) upon slugs (Gastropoda: Pulmonata) in an arable field. J. Appl. Ecol. 33: 741-753.

SyMONDSON W.O.C., ERICKSON M.L., LidDELl J.E. \& JAYAWARDENA K.G.I. 1999a: Amplified detection using a monoclonal antibody of an aphid-specific epitope exposed during digestion in the gut of a predator. Insect Biochem. Molec. Biol. 29: 873-882.

Symondson W.O.C., ERICKSON M.L. \& Liddell J.E. 1999b: Development of a monoclonal antibody for the detection and quantification of predation on slugs within the Arion hortensis agg. (Mollusca: Pulmonata). Biol. Control 16: 274-282.

Symondson W.O.C., Sunderland K.D. \& Greenstone M.H. 2002: Can generalist predators be effective biocontrol agents? Annu. Rev. Entomol. 47: 561-594.
ToFt S. 1997: Acquired food aversion of a wolf spider to three cereal aphids: intra- and interspecific effects. Entomophaga 42: 63-69.

TriLTSCH H. 1997: Contents in field sampled adults of Coccinella septempunctata (Col.: Coccinellidae). Entomophaga 42: 125-131.

TriLTSCH H. 1999: Food remains in the guts of Coccinella septempunctata (Coleoptera: Coccinellidae) adults and larvae. Eur. J. Entomol. 96: 355-364.

TURNER B.D. 1984: Predation pressure on the arboreal epiphytic herbivores of larch trees in southern England. Ecol. Entomol. 9: 91-100.

Vickerman G.P. \& SunderLAND K.D. 1975: Arthropods on cereal crops: nocturnal activity, vertical distribution and aphid predation. J. Appl. Ecol. 12: 755-766.

Winder L., Hirst D.J., Carter N., Wratten S.D. \& Sopp P.I. 1994: Estimating predation of the grain aphid Sitobion avenae by polyphagous predators. J. Appl. Ecol. 31: 1-12.

Winder L., Alexander C.J., Holland J.M., Symondson W.O.C., Perry J. \& Woolley C. 2005: Predatory activity and spatial pattern: the response of generalist carabids to their aphid prey. J. Anim. Ecol. (in press).

Woodward G. \& HiLdRew A.G. 2002: Body-size determinants of niche overlap and intraguild predation within a complex food web. J. Anim. Ecol. 71: 1063-1074.

Zaidi R.H., JaAl Z., Hawkes N.J., Hemingway J. \& Symondson W.O.C. 1999: Can multiple- copy sequences of prey DNA be detected amongst the gut contents of invertebrate predators? Mol. Ecol. 8: 2081-2088.

Received September 10, 2004; revised and accepted May 16, 2005 